\title{
Mesenchymal Stem Cell-Derived Exosomes for COVID-19 Therapy, Preclinical and Clinical Evidence
}

\author{
Nasim Kiaie ${ }^{1,2}$, Seyedeh Parvin Mousavi Ghanavati, ${ }^{3, *}$, Sara Sadat Miremadi, ${ }^{4, *}$, Azam Hadipour ${ }^{5}$, \\ Rouhollah Mehdinavaz Aghdam ${ }^{1}$ \\ ${ }^{1}$ School of Metallurgy \& Materials Engineering, College of Engineering, University of Tehran, Tehran, Iran \\ ${ }^{2}$ Research Center for Advanced Technologies in Cardiovascular Medicine, Tehran Heart Center, Tehran University of Medical Sciences, \\ Tehran, Iran \\ ${ }^{3}$ Ahvaz fundishapur University of Medical Sciences, Ahvaz, Iran \\ ${ }^{4}$ Stem Cell \& Regenerative Medicine Center of Excellence, Tehran University of Medical Sciences, Tehran, Iran \\ ${ }^{5}$ Tarmim Ava Baran Company, Tehran, Iran
}

Since the emergence of the novel coronavirus, named COVID-19, researchers are looking for a treatment to stop the devastating pandemic. During these efforts, mesenchymal stem cells (MSCs), the potential next generation of therapeutic methods with wide application for diseases, have successfully controlled cytokine storm following the virus infection. However, the use of MSCs has been limited due to the ethical issues, immunogenicity, and genetic modifications. Therefore, exosomes were introduced as a suitable substitute for the MSCs. In the case of COVID-19 treatment, both MSCs and exosomes exert their beneficial effect mainly through the management of the cytokine storm. This study provided the underlying mechanisms for the effect of exosomes on COVID-19 treatment and presented several preclinical and clinical studies of exosomes for COVID-19 treatment.

Keywords: COVID-19, Exosome, Stem cells, Cytokine storm

\section{Introduction to COVID-19 and Treatments}

In December 2019, a novel coronavirus, named SARSCoV-2, COVID-19, or 2019-nCoV, was recognized in

Received: November 3, 2020, Revised: March 31, 2021,

Accepted: April 22, 2021, Published online: June 30, 2021

Correspondence to Rouhollah Mehdinavaz Aghdam

School of Metallurgy \& Materials Engineering, College of Engineering, University of Tehran, after jalal Al Ahmad St., North Kargar St., Tehran 11155-4563, Iran

Tel: +98-21-88012999, Fax: +98-21-88006076

E-mail: mehdinavaz@ut.ac.ir

*These authors contributed equally to this work.

(c) This is an open-access article distributed under the terms of the Creative Commons Attribution Non-Commercial License (http://creativecommons.org/ licenses/by-nc/4.0/), which permits unrestricted non-commercial use, distribution, and reproduction in any medium, provided the original work is properly cited.

Copyright (c) 2021 by the Korean Society for Stem Cell Research
Wuhan city and turned into a pandemic at a fast rate. The danger of producing severe acute respiratory syndrome in many people infected with the highly contagious virus resulted in activity restrictions, economic recession, and the collapse of the health care systems around the world (1, 2). Despite some asymptomatic patients or those with mild symptoms, acute respiratory distress syndrome (ARDS) and ultimately multiple organ failure (MOF) was evident in the elderly, as well as cases with chronic lung disease, diabetes mellitus, and cardiovascular diseases comprising $10 \sim 34 \%$ of the whole virus-infected population $(3,4)$. Therefore, scientists have launched a big competition to find solutions for the management of the deadly coronavirus. Their attempts have been expanded from repurposing drugs that are already approved for other diseases to the invention of new drugs and therapeutic methods. Examples of effective drugs for COVID-19 treatment in animals that are used basically for other diseases 
are remdesivir (an antiviral), chloroquine (a malaria medication), lopinavir (an drug for human immunodeficiency [HIV] virus) combined to ritonavir, and a combination of lopinavir/ritonavir/interferon-beta $(5,6)$. Other options exist for the prevention and treatment of COVID-19 including vaccination and plasma transmission; however, the efficacy of these two methods requires stable viral epitopes while the RNA in this novel virus mutates rapidly and suppresses host $\mathrm{T}$ cell function that leads to frequent presentations of MOF in the setting of immunodeficiency even in healthy individuals (7).

As another therapeutic option, stem cell-based therapies have emerged for COVID-19 management. Despite significant progress, stem cell-based therapies are still accompanied by limitations including immunogenicity, limited cell source, and ethical concerns, rendering their clinical use (8). Additionally, it has been distinguished that the main mechanism of stem cell efficacy for COVID-19 treatment is the management of the cytokine storm through their paracrine effects (9-11). Therefore, stem cell-derived exosomes have been introduced as an alternative to stem cells considering their abilities to manage cytokine storm and not having stem cell-related problems $(12,13)$. In this study, the application of exosomes as a potential treatment for ARDS produced in COVID-19-infected patients is discussed. After presenting an introductory section on mechanisms of action of exosomes for ARDS management, different pre-clinical, and the most updated clinical practices of exosome therapy for COVID-19 treatment is discussed.

\section{Cytokine Storm in COVID-19}

The coronavirus structure is a non-segmented positive-sense single-stranded RNA, with 26 to $32 \mathrm{~kb}$ in length, covered with structural proteins consists of a spike $(\mathrm{S})$, envelope (E), membrane (M), and nucleocapsid (N) protein. Among these structural proteins, the role of $\mathrm{S}$ protein in virus entry and replication in the host cell is more considerable. Binding this protein to the angiotensin-converting enzymes 2 (ACE2), a type of receptor expressed on the surface of human cells especially in the alveolar type II cells, results in virus entry and then virus replication with the help of the host machinery. Virus entrance into the lung causes massive alveolar damage, major histological changes, interstitial inflammation, intra-alveolar edema, granular tissue formation, fibrin and collagen deposition, bronchiolitis and leukocyte infiltration, pneumonia, and ultimately progressive respiratory failure (14-16). All these events take place following an ex- cessive immune response induction, also known as a cytokine storm, that sharply increase inflammatory cytokines such as interleukin-2 (IL-2), IL-7, IL-10, granulocyte-colony stimulating factor (G-CSF), interferon- $\gamma$-inducible protein-10 (IP-10), monocyte chemoattractant protein-1 (MCP-1), macrophage inflammatory protein-1 alpha (MIP-1A), and tumor necrosis factor-alpha (TNF $\alpha$ ) (17).

The studies have shown the effectiveness of MSCs in preventing the excessive release of cytokines by immune cells $(14,18-20)$. The mechanisms of stem cells' effect on cytokine storm have been attributed to 1) diminishing the level of chemokines and proinflammatory cytokines through IL-1 receptor agonist release, generating TNF $\alpha$ -stimulated gene-6 (TSG-6), and finally downregulating $\mathrm{NF}-\kappa \mathrm{B}$ signaling $(21) ; 2)$ targeting T-lymphocytes and down-regulating their proliferation or preventing the infiltration of inflammatory cells into the lungs $(22,23) ; 3)$ increasing B lymphocytes, natural killer (NK) cells, and dendritic cells (DC) (24); and 4) releasing cytokines including tissue growth factor-beta (TGF- $\beta$ ), hepatocytic growth factor (HGF), prostaglandin E2 (PGE2), and IL-10 (25). As presented in Fig. 1, secretion of different factors from MSCs modulate the cytokine storm following COVID-19 infection (10).

\section{The Role of Exosomes in the Management of Cytokine Storm}

Exosomes with endosomal origin are small vesicles of $30 \sim 130 \mathrm{~nm}$ size rich in proteins like heat shock proteins, annexins, cytoskeletal proteins, signal transduction proteins, and multivesicular body synthesis proteins. The content of exosomes depends on the parent cell from which they are secreted. They also carry biological membrane proteins, cytosolic proteins, transcription factors, messenger RNA (mRNA), ribosomal RNA (rRNA), micro RNA (miRNA), various signal transduction molecules, and cell adhesion molecules on their surface for binding to the target cell (26-28).

MSCs, as one important cell types for the stem cell therapies application, manage the cytokine storm following COVID-19 infection through their paracrine effects. The research has shown that exosomes are as effective as MSCs in the management of cytokine storm so that in a pattern similar to MSCs, exosomes downregulate T-cells proliferation, induce auto-reactive lymphocytes for the apoptosis of activated $\mathrm{T}$ cells, and secrete anti-inflammatory cytokines such as IL-10 and TGF- $\beta(15,29,30)$. Exosomes also induce polarization of $\mathrm{Ml}$ macrophages to M2 phenotype, an inhibitor of pro-inflammatory cyto- 


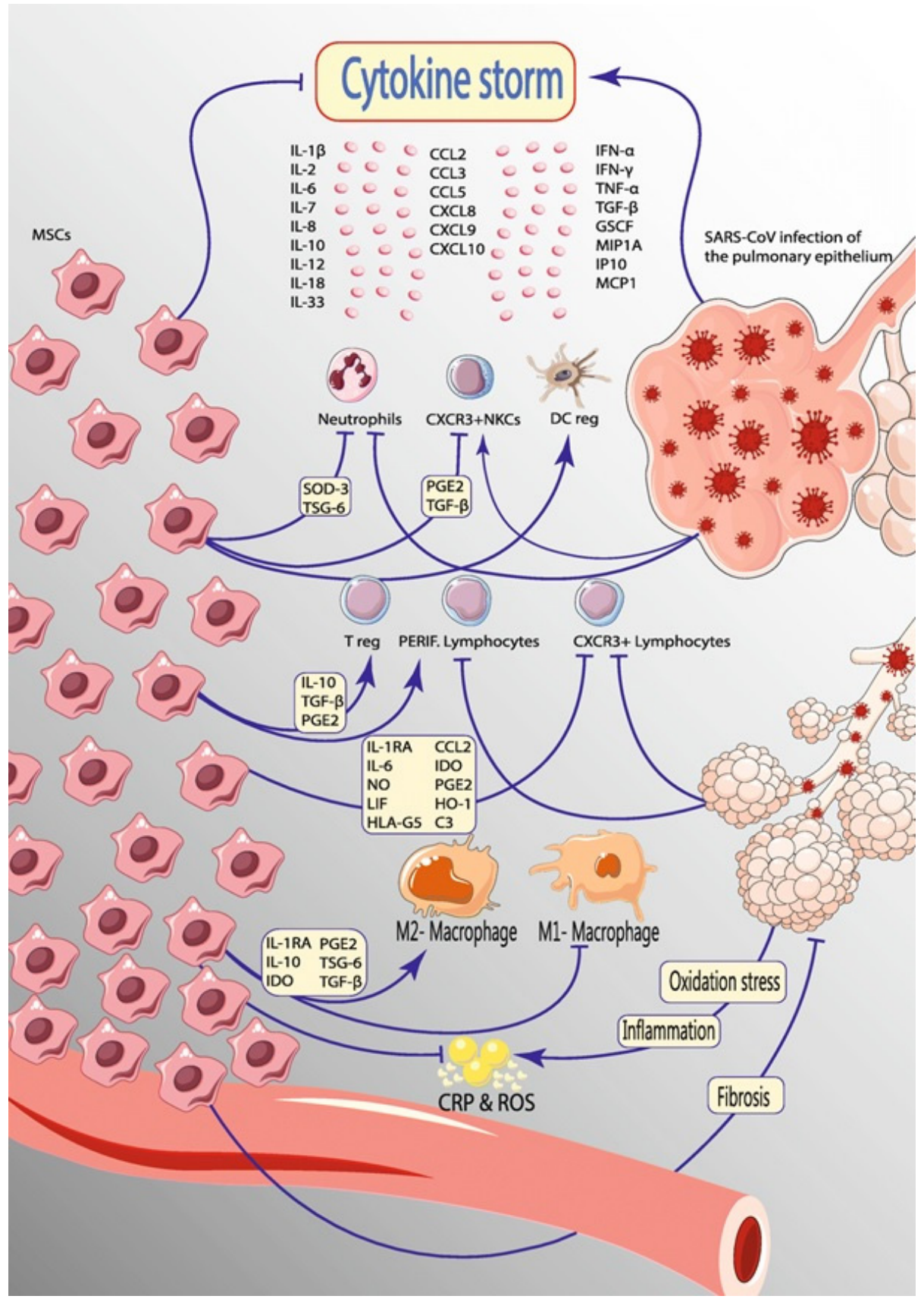

Fig. 1. Immunomodulation effect of mesenchymal stem cells on cytokines storm led by COVID-19. When SARS-CoV-2 enters the lungs, it attracts immune cells to infection areas and localizes inflammation. The lethal unchecked systemic inflammatory response is caused by the secretion of large levels of pro-inflammatory cytokines such as interleukin, interferons, chemokines, and other factors by immune effector cells in this infection. After MSC therapy, these cells reach the lung tissue and secrete factors that can modulate the immune system; they also can prevent ROS and even fibrosis of the lung tissue. Abbreviation: ARDS: acute respiratory distress syndrome, COVID-19: coronavirus disease 2019, CCL: chemokine (C-C motif) ligand, CXCL: chemokine (C-X-C motif) ligand, C3: Complement component 3, CRP: C-reactive protein, DC reg: regulatory dendritic cells, GSCF: granulocyte colony-stimulating factor, HO-1: Heme oxygenase-1, HLA-G5: human leukocyte antigen-G, IL: interleukin, IFN: interferon, IP10: IFN- $\gamma$-Inducible Protein 10, IL-1RA: interleukin-1 receptor antagonist, LIF: leukemia inhibitory factor, IDO: Indoleamine 2,3-dioxygenase, MSCs: mesenchymal stem cells, MIP1A: Macrophage Inflammatory Protein 1 Alpha, MCP1: monocyte chemoattractant protein 1, NKCs: natural killer cells, NO: nitric oxide, PERIF: peripheral, PGE2: Prostaglandin $\mathrm{E}_{2}$, ROS: reactive oxygen species, SARS-CoV: severe acute respiratory-associated coronavirus, SOD-3: superoxide dismutase, TSG-6: TNF $\alpha$-stimulated gene-6, TGF- $\beta$ : transforming growth factor, Treg: regulatory T. With permission from Kavianpour et al. 2020 (10). 
kines, and upregulate miR-146a expression which is known to exert anti-inflammatory effects (31).

Several mechanisms underlying the effect of stem cell-derived exosomes in COVID-19 improvements in preclinical models of ARDS are suggested. For example, Zhu et al. (32) reported that the secretion of some soluble factors such as keratinocyte growth factor (KGF) following exosome therapy lead to the reduction of alveolar inflammation. In another case, Li et al. (33) employed a murine lung ischemia/reperfusion (I/R) model to show that bone marrow MSC-derived exosomes reduce lung $\mathrm{I} / \mathrm{R}$ by transporting miR-21, an anti-apoptotic miRNA. They have demonstrated that intratracheal administration of either MSC-derived exosome or miR-21-5p alleviates lung edema and repress the secretion of high mobility group box protein 1 (HMGB1), IL-8, IL-1 $\beta$, IL-6, IL-17, and TNF- $\alpha$ (33). Monsel et al. (34) also reported reduced secretion of inflammatory cytokines during an effort to study the effect of MSCs-derived exosomes on lung inflammation and bacterial clearance in mice suffering from severe Escherichia coli (E. coli) pneumonia. Exosomes also lowered inflammatory cytokines and increased intracellular ATP levels in the alveolar epithelial type II cells (34).

Other studies suggested the role of miRNA-126 in the alveolar-epithelial barrier and therefore affecting lung inflammation following exosomes administration (35). The important role of the CD44 receptors in the exosome effect and the necessity of this receptor for the exosome uptake has been evidenced by the co-administration of exosomes with anti-CD44 in human lungs $(34,36)$. In another work, Khatri et al. (37) collected exosomes from a conditioned medium of swine bone marrow MSCs by ultracentrifugation and then used them in influenza virus-induced acute lung injury (ALI) pig model. The inhibitory effect of a certain exosome concentration on hemagglutination activity of influenza viruses which resulted in a reduction of pro-inflammatory cytokines (TNF- $\alpha$, CXCL10, IL-10) was considered as the reason behind the beneficial effects of exosome (37). Tang et al. (38) suggested that reduced inflammation and recovery of the alveolar-capillary barrier in a mouse model of ALI following exosome treatment is due to improved KGF and angiopoietin-1 (Ang-1) mRNA expression. Increasing Angl secretion following the release of MSC-derived exosomes restores lung protein permeability across Human Lung Micro Vascular Endothelial Cells (HLMVECs), as was reported by $\mathrm{Hu}$ et al. (39).

\section{The Diverse Sources of MSC-Derived Exosomes as Therapeutic Approach for COVID}

The source of MSC-derived exosomes is a determining factor in its therapeutic effect. Bone marrow has been the main source of MSC-derived exosomes in many studies while umbilical cord MSCs have been used for exosome extraction in a study (40). In this study, Varkouhi et al. (40) showed that exosomes derived from umbilical cord MSCs have a therapeutic effect on E. coli-induced ALI in rats. Bacterial phagocytosis by macrophages and endothelial nitric oxide synthase were ameliorated and alveolar-arterial oxygen gradient, protein leak, and alveolar TNF- $\alpha$ concentration were decreased (40). Zhu et al. (32) extracted exosomes from bone marrow-derived MSC using ultracentrifugation. After induction of ALI in mice by the intratracheal instillation of a nonlethal dose of endotoxin from $E$. coli, Zhu's team indicated that MSC-derived exosomes lead to improved indices of ALI after 48 hours and reduced extravascular lung water, and total protein levels in bronchoalveolar lavage fluid (32). Park et al. (41) also utilized exosomes derived from bone marrow MSCs in an ex vivo experiment in a human model of bacterial pneumonia induced by intra-bronchial insertion of $E$. coli. They observed increased alveolar fluid clearance, reduced protein permeability, and lower bacterial load in the injured alveolus (41).

\section{Preclinical Studies on MSC-Derived Exosome for COVID-19 Treatment}

Several preclinical studies has shown the effectiveness of exosomes derived from MSCs for the management of ARDS and ALI as presented in Table 1. This suggests the potential use of exosomes for the management of ARDS in acute cases of COVID-19 infection.

\section{Clinical Trials on MSC-Derived Exosome for COVID-19 Treatment and Their Limitations}

Since the onset of the pandemic, only a research group has completed the study of the safety and effectiveness of MSC-derived exosome administration to the COVID-19 patients (18). In this prospective nonrandomized open-label cohort study, $15 \mathrm{ml}$ exosomes derived from bone marrow MSCs delivered intravenously to 24 severe COVID-19 patients (18). The safety of the exosome was confirmed after observing no adverse effect within $72 \mathrm{~h}$ of injection. Improved clinical status evidenced by a $192 \%$ increase in the average pressure of arterial oxygen to fraction of in- 
Table 1. MSC-derived exosomes in preclinical models of ARDS and ALI

\begin{tabular}{|c|c|c|c|c|}
\hline PubMed & $\begin{array}{l}\text { EVs-MSCs } \\
\text { source }\end{array}$ & Disease model & Therapeutic EVs dose & Outcomes \\
\hline 23939814 & $\begin{array}{l}\text { Human bone } \\
\text { marrow }\end{array}$ & $\begin{array}{l}\text { Male C57BL/6 mice with } \\
\text { E. coli endotoxin-induced } \\
\text { ALI }\end{array}$ & $\begin{array}{l}\text { EVs from 750,000 } \\
\text { cells }\end{array}$ & $\begin{array}{l}\text { - Reduced inflammatory cell influx } \\
\text { - Reduced EVLW } \\
\text { - Reduced alveolar MIP-2 protein } \\
\text { - Expression of KGF mRNA } \\
\text { - Increased KGF } \\
\text { - Increased IL-10 }\end{array}$ \\
\hline 30682335 & $\begin{array}{l}\text { Human bone } \\
\text { marrow }\end{array}$ & $\begin{array}{l}\text { Male C57BL/6 mice with } \\
\text { lung ischemia/reperfusion } \\
\text { Murine primary pulmonary } \\
\text { endothelial cells }\end{array}$ & EVs from $2 \times 10^{6}$ cells & $\begin{array}{l}\text { - Reduced lung edema } \\
\text { - Reduced IL-8, IL-6, IL-17, IL-1 } \beta, \text { TNF- } \alpha \text {, HMGB1 } \\
\text { - Reduced alveolar macrophage M1 polarization }\end{array}$ \\
\hline 30076187 & $\begin{array}{l}\text { Human bone } \\
\text { marrow }\end{array}$ & $\begin{array}{l}\text { Mice with E. Coli induced } \\
\text { ALI }\end{array}$ & EVs from $1 \times 10^{6}$ cells & $\begin{array}{l}\text { - Increased AFC rate } \\
\text { - Increased antimicrobial effect } \\
\text { - Decreased lung protein permeability } \\
\text { - Decreased bacterial CFU }\end{array}$ \\
\hline 25847030 & $\begin{array}{l}\text { Human bone } \\
\text { marrow }\end{array}$ & $\begin{array}{l}\text { Ex vivo perfused human lung } \\
\text { (rejected for the transplant) }\end{array}$ & $100 \mu \mathrm{IEV}$ & $\begin{array}{l}\text { - Increased AFC rate } \\
\text { - Decreased lung weight gain } \\
\text { - Increased lung compliance } \\
\text { - Decreased pulmonary artery pressure and resistance } \\
\text { - Increased NO in perfusate } \\
\text { - Decreased pH of perfusate } \\
\text { - Decreased elevation of lactate }\end{array}$ \\
\hline 28376568 & $\begin{array}{l}\text { Human bone } \\
\text { marrow }\end{array}$ & $P$. aeruginosa induced mouse & $\begin{array}{l}10 \mu \mid \text { EVs from } \\
1 \times 10^{6} \text { cells }\end{array}$ & $\begin{array}{l}\text { - Decreased WBC influx } \\
\text { - Decreased MIP-2 secretion } \\
\text { - Restoration of pulmonary capillary } \\
\text { - Expression of Ang-1 mRNA } \\
\text { - Increased alveolar Ang-1 } \\
\text { - Decreased TNF- } \alpha \\
\text { - Increased IL-10 }\end{array}$ \\
\hline 26067592 & $\begin{array}{l}\text { Human bone } \\
\text { marrow }\end{array}$ & $\begin{array}{l}\text { Male C57BL/6 mice with } \\
\text { E. coli induced ALI }\end{array}$ & $\begin{array}{l}30 \text { or } 60 \mu l \\
\text { (intratracheal) } \\
90 \mu l \text { (i.v. injection) }\end{array}$ & $\begin{array}{l}\text { - Decreased total bacterial load } \\
\text { - Decreased inflammation } \\
\text { - Decreased lung protein permeability } \\
\text { - Increased monocyte phagocytosis } \\
\text { - Decreased TNF- } \alpha \text { by LPS primed human monocytes } \\
\text { - Increased COX2 and IL-10 mRNA expression } \\
\text { - Increased IL-10 secretion by monocytes } \\
\text { - Decreased bacterial CFU }\end{array}$ \\
\hline 29378639 & $\begin{array}{l}\text { Human bone } \\
\text { marrow }\end{array}$ & Influenza virus-infected pig & $\begin{array}{l}\text { EVs from } \\
10 \times 10^{6} \text { cells }\end{array}$ & $\begin{array}{l}\text { - Decreased Haemagglutination activity of influenza } \\
\text { viruses } \\
\text { - Decreased virus replication } \\
\text { - Decreased lung inflammation } \\
\text { - Decreased virus replication } \\
\text { - Decreased pro-inflammatory cytokine production } \\
\text { - Increased IL-10 }\end{array}$ \\
\hline 29737632 & $\begin{array}{l}\text { Human bone } \\
\text { marrow }\end{array}$ & $\begin{array}{l}\text { HLMVECs injured by } \\
\text { cytomix (IL- } 1 \beta, \text { TNF- } \alpha \text {, } \\
\text { and IFN- } \gamma)\end{array}$ & $\begin{array}{l}20 \mu \mid \text { EVs from } \\
1 \times 10^{6} \text { cells }\end{array}$ & $\begin{array}{l}\text { - Restoring protein permeability across injured } \\
\text { HLMVECs } \\
\text { - Preventing actin stress fibers formation } \\
\text { - Preventing reorganization of cytoskeleton protein } \\
\text { F-actin into actin stress fiber in cytomix injured } \\
\text { HLMVEC } \\
\text { - Restoring the VE-cadherin (adherens junction) and } \\
\text { ZO-1 (tight junction) in HMVEC injured by cytomix } \\
\text { - Increased Ang-1 mRNA expression }\end{array}$ \\
\hline
\end{tabular}


Table 1. Continued

\begin{tabular}{|c|c|c|c|c|}
\hline PubMed & EVs-MSCs source & Disease model & Therapeutic EVs dose & Outcomes \\
\hline 30870158 & $\begin{array}{l}\text { Human umbilical } \\
\text { cord }\end{array}$ & Rat with $E$. coli induced ALI & $\begin{array}{l}\text { EVs from } \\
100 \times 10^{6} \text { cells }\end{array}$ & $\begin{array}{l}\text { - Increased survival } \\
\text { - Reduced alveolar-arterial oxygen gradient } \\
\text { - Reduced alveolar protein leak } \\
\text { - Increased lung mononuclear phagocytes } \\
\text { - Reduced alveolar TNF- } \alpha \text { concentrations } \\
\text { - Enhanced endothelial NOS production }\end{array}$ \\
\hline
\end{tabular}

Abbreviations: EVs: Extracellular Vesicles, HLMVECs: Human Lung Micro Vascular Endothelial Cells, ZO: Zonula Occludens, MSC: Mesenchymal Stem Cells, EVLW: Extravascular Lung Water, MIP-2: Macrophage Inflammatory Protein 2, KGF: Keratinocyte Growth Factor, IL: Interleukin, TNF: Tumor Necrosis Factor, HMGB 1: High Mobility Group Box 1, CFU: Colony-Forming Unit, WBC: White Blood Cell, LPS: Lipopolysaccharides, COX: Cyclooxygenase, NOS: nitric oxide synthase.

Table 2. Ongoing clinical trials of exosomes derived from MSCs or other cell types for COVID-19 therapy before February 26,2021

\begin{tabular}{|c|c|c|c|c|c|}
\hline Study ID & EVs source & $\begin{array}{l}\text { Delivery } \\
\text { mode }\end{array}$ & EVs dose & $\begin{array}{l}\text { Study phase; } \\
\text { participant (n) }\end{array}$ & Outcomes \\
\hline NCT04602442 & $\mathrm{N} / \mathrm{A}$ & Inhalation & $\begin{array}{l}0.5-2 \times 10^{10} \text { exosome/ } \\
3 \mathrm{ml} \text {, twice a day } \\
\text { for } 10 \text { days }\end{array}$ & II; $\mathrm{n}=90$ & $\begin{array}{l}\text { - Adverse events } \\
\text { - TTCR } \\
\text { - Blood biochemistry } \\
\text { - SpO2 concentration changes } \\
\text { - Chest imaging changes }\end{array}$ \\
\hline NCT04491240 & MSC & Inhalation & $\begin{array}{l}0.5-2 \times 10^{10} \text { exosome/ } \\
3 \mathrm{ml} \text {, twice a day } \\
\text { for } 10 \text { days }\end{array}$ & I \& II; $n=90$ & $\begin{array}{l}\text { - Adverse events } \\
\text { - TTCR } \\
\text { - Blood gases changes } \\
\text { - SpO2 concentration changes } \\
\text { - Chest imaging changes }\end{array}$ \\
\hline NCT04389385 & $\mathrm{T}$ cells & Inhalation & $\begin{array}{l}2 \times 10^{8} \text { exosome } / 3 \mathrm{ml} ; \\
\text { daily for } 5 \text { days }\end{array}$ & $\mathrm{I} ; \mathrm{n}=60$ & $\begin{array}{l}\text { - Adverse events } \\
\text { - TTCR } \\
\text { - Rate of recovery without a mechanical ventilator }\end{array}$ \\
\hline NCT04384445 & $\begin{array}{l}\text { Human } \\
\text { amniotic } \\
\text { fluid }\end{array}$ & $\begin{array}{l}\text { Intravenous } \\
\text { infusion }\end{array}$ & $\begin{array}{l}2-5 \times 10^{11} \text { exosome/ } \\
1 \mathrm{ml} \text {, day } 0 \text {, day } 4, \\
\text { and day } 8\end{array}$ & I \& II; $n=20$ & $\begin{array}{l}\text { - Adverse events } \\
\text { - } 60 \text {-day mortality } \\
\text { - Survival rate } \\
\text { - Levels of cytokines, D-dimer, CRP } \\
\text { - Viral load } \\
\text { - Improved organ failure } \\
\text { - Chest imaging changes }\end{array}$ \\
\hline NCT04493242 & $\begin{array}{l}\text { Bone } \\
\text { marrow }\end{array}$ & $\begin{array}{l}\text { Intravenous } \\
\text { injection }\end{array}$ & $\mathrm{N} / \mathrm{A}$ & II; $\mathrm{n}=60$ & $\begin{array}{l}\text { - 28-day mortality } \\
\text { - Median days to recovery }\end{array}$ \\
\hline NCT04276987 & MSC & Inhalation & $\begin{array}{l}2 \times 10^{8} \text { exosome } / 3 \mathrm{ml} \\
\text { daily for } 5 \text { days }\end{array}$ & $\mathrm{I} ; \mathrm{n}=30$ & $\begin{array}{l}\text { - Adverse events } \\
\text { - TTCR } \\
\text { - Number of patients weaning from mechanical } \\
\text { ventilation } \\
\text { - Days of ICU monitoring } \\
\text { - Days of vasoactive agents' usage } \\
\text { - Days of mechanical ventilation } \\
\text { - Number of patients with improved organ failure } \\
\text { - 28-day mortality }\end{array}$ \\
\hline
\end{tabular}

spired oxygen ratio $(\mathrm{PaO} 2 / \mathrm{FiO} 2)$ showed the effectiveness of the therapy. Increased neutrophil and lymphocyte count, as well as reduced C-reactive protein, ferritin, and D-dimer, represent effective regulation of cytokine storm via exosome (18).

Besides, a handful of clinical studies are performed on exosome therapy in COVID-19 patients. After searching the words "exosome" and "COVID-19' in clinical trial da- 
Table 2. Continued

\begin{tabular}{|c|c|c|c|c|c|}
\hline Study ID & EVs source & Delivery mode & EVs dose & $\begin{array}{l}\text { Study phase; } \\
\text { participant (n) }\end{array}$ & Outcomes \\
\hline NCT04747574 & $\begin{array}{l}\text { T-REx }{ }^{\mathrm{TM}}- \\
293 \text { cells }\end{array}$ & Inhalation & $\begin{array}{l}1 \times 10^{9} \\
\text { exosome/ } \\
2 \mathrm{ml} \text {, daily } \\
\text { for } 5 \text { days }\end{array}$ & $\mathrm{I} ; \mathrm{n}=30$ & $\begin{array}{l}\text { - Adverse events } \\
\text { - Survival at Day } 5 \\
\text { - SpO2 saturation measurement } \\
\text { - Respiratory rate measurement } \\
\text { - Proportion of patients with no artificial } \\
\text { ventilation } \\
\text { - Change in the absolute lymphocyte count from } \\
\text { baseline } \\
\text { - Change in neutrophil-to-lymphocyte ratio }\end{array}$ \\
\hline $\begin{array}{l}\text { ISRCTN } \\
33578935\end{array}$ & Placental MSC & Intravenous infusion & $\begin{array}{l}0.2 \mathrm{mg} / \mathrm{kg}, 15 \\
\mathrm{ml} \text {, on day } 1 \\
\text { and day } 3\end{array}$ & II; $n=64$ & $\begin{array}{l}\text { - Adverse events } \\
\text { - } \mathrm{PaO} 2 / \mathrm{FiO} 2 \text { ratio }\end{array}$ \\
\hline $\begin{array}{c}\text { IRCT20200510 } \\
\text { 047385N1 }\end{array}$ & $\begin{array}{l}\text { Condition } \\
\text { media of SVF } \\
\text { and blood }\end{array}$ & $\begin{array}{l}\text { Injection into the } \\
\text { patient's lungs } \\
\text { through the trachea }\end{array}$ & $\begin{array}{l}10 \mathrm{ml} \text { daily } \\
\text { for } 3 \text { days }\end{array}$ & II \& III; $n=60$ & $\begin{array}{l}\text { - SOFA score } \\
\text { - Lung damage score } \\
\text { - Inflammatory status (IL1, IL6) } \\
\text { - Oxidative status (TAC) }\end{array}$ \\
\hline $\begin{array}{l}\text { ChiCTR } \\
2000030261\end{array}$ & MSC & Inhalation & N/A & $\mathrm{N} / \mathrm{A} ; \mathrm{n}=26$ & $\begin{array}{l}\text { - Lung CT } \\
\text { - Nucleic acid detection of pharyngeal test } \\
\text { - Leukocytes and lymphocytes count }\end{array}$ \\
\hline $\begin{array}{l}\text { ChiCTR } \\
2000030484\end{array}$ & N/A & Intravenous injection & $\begin{array}{c}180 \mathrm{mg} / \text { day, } \\
\text { for } 7 \text { days }\end{array}$ & $\mathrm{N} / \mathrm{A} ; \mathrm{n}=90$ & $\begin{array}{l}\text { - Adverse events } \\
\text { - PaO2/FiO2 or respiratory rate (without oxygen) } \\
\text { - Frequency of respiratory exacerbation } \\
\text { - Physical signs and symptoms } \\
\text { - TTCR } \\
\text { - The number and range of lesions indicated by } \\
\mathrm{CT} \text { and X-ray of the lung } \\
\text { - Time for the cough to become mild or absent } \\
\text { - Time for dyspnea to become mild or no dyspnea } \\
\text { - Frequency of oxygen inhalation or noninvasive } \\
\text { ventilation } \\
\text { - Frequency of mechanical ventilation } \\
\text { - Inflammatory cytokines (CRP/PCT/SAA, etc.) }\end{array}$ \\
\hline
\end{tabular}

Abbreviations: EVs: Extracellular vesicles, TTCR: Time to clinical recovery, SVF: stromal vascular fractions, CRP: C-reactive protein, PCT: Procalcitonin, SAA: serum amyloid A, HAF: human amniotic fluid, TAC: total antioxidant capacity, SOFA: Sequential Organ Failure Assessment.

tabases including ClinicalTrials.gov, ISRCTN registry, the International Clinical Trials Registry Platform (ICTRP), EU Clinical Trials Register, Cochrane Central Register of Controlled Trials (CENTRAL), trials listed in Table 1 were identified before February 26, 2021 (Table 2).

Although the clinical use of exosomes for the treatment of different diseases has shown promising results, there are still challenges for entering exosome into the clinic. The most important challenge is the differences in the source of exosomes (MSCs from different origins or other cells types such as $\mathrm{T}$ cells), different isolation and purification protocols that result in different yields, exosome function, and the possibility of exosome contamination with other types, all hinder acquiring homogenous exo- somes and standardization of clinical practices (42). Suggesting harmonized methods of purifying and characterizing exosomes by members of societies including the society for clinical research and translation of extracellular vesicles Singapore (SOCRATES), the international society for extracellular vesicles (ISEV), the international society for cellular and gene therapies (ISCT), and the international society of blood transfusion (ISBT) is an effective movement for obtaining and sharing comparable data (43).

The time-consuming process of exosome extraction and acquiring a low yield due to exosome damage during this process is also problematic (44). Since the exosome characteristics are dependent on several factors including iso- 
lation method, culture conditions, the type of cell treatments, etc., batch-to-batch variations of exosomes are highly probable that might produce different results in patients during a clinical study (45).

It worth noting that the physiological state of patients and the existence of some underlying diseases such as cancer or HIV might alter molecular cargos of exosomes (46, 47). Exosome usage may also be contraindicated when the patients use specific drugs (35). Therefore, inclusion and exclusion criteria should be selected with care.

\section{Conclusions}

The success of exosome in controlling cytokine storm and reducing ARDS in acute cases of COVID-19, as well as the benefits of using exosomes instead of stem cells, suggest that exosomes have the potential to be used clinically for improving the well-being of patients infected with COVID-19 and developed respiratory syndromes. However, exosomes extracted from cells with different sources have shown different therapeutic effects on COVID-19 improvement. Before the widespread use of exosomes, it is necessary to control not only the source of exosomes but also the isolation, purification, and characterization methods precisely to prevent uncontrolled effects on different patients.

\section{Acknowledgments}

We appreciate the financial support from Tarmim Ava Baran Company, a company producing tissue engineering-based products and medical devices in Iran.

\section{Potential Conflict of Interest}

The authors have no conflicting financial interest.

\section{References}

1. Zhou F, Yu T, Du R, Fan G, Liu Y, Liu Z, Xiang J, Wang Y, Song B, Gu X, Guan L, Wei Y, Li H, Wu X, Xu J, Tu $\mathrm{S}$, Zhang Y, Chen H, Cao B. Clinical course and risk factors for mortality of adult inpatients with COVID-19 in Wuhan, China: a retrospective cohort study. Lancet 2020; 395:1054-1062

2. Zu ZY, Jiang MD, Xu PP, Chen W, Ni QQ, Lu GM, Zhang LJ. Coronavirus disease 2019 (COVID-19): a perspective from China. Radiology 2020;296:E15-E25

3. Pinky, Gupta S, Krishnakumar V, Sharma Y, Dinda AK, Mohanty S. Mesenchymal stem cell derived exosomes: a nano platform for therapeutics and drug delivery in combating COVID-19. Stem Cell Rev Rep 2021;17:33-43

4. Lee PI, Hsueh PR. Emerging threats from zoonotic corona- viruses-from SARS and MERS to 2019-nCoV. J Microbiol Immunol Infect 2020;53:365-367

5. Kupferschmidt K, Cohen J. Race to find COVID-19 treatments accelerates. Science 2020;367:1412-1413

6. Sanders JM, Monogue ML, Jodlowski TZ, Cutrell JB. Pharmacologic treatments for coronavirus disease 2019 (COVID-19): a review. JAMA 2020;323:1824-1836

7. Soltani S, Zakeri AM, Karimi MR, Rezayat SA, Anbaji FZ, Tabibzadeh A, Yousefi P, Zakeri A, Jafarpour A, Norouzi M, Erfani Y, Poortahmasebi V. A systematic literature review of current therapeutic approaches for COVID-19 patients. J Pharm Res Int 2020;32:13-25

8. Golchin A, Farahany TZ. Biological products: cellular therapy and FDA approved products. Stem Cell Rev Rep 2019; 15:166-175

9. Akkoc T. COVID-19 and mesenchymal stem cell treatment; mystery or not. Adv Exp Med Biol 2020;1298:167-176

10. Kavianpour M, Saleh M, Verdi J. The role of mesenchymal stromal cells in immune modulation of COVID-19: focus on cytokine storm. Stem Cell Res Ther 2020;11:404

11. Raza SS, Khan MA. Mesenchymal stem cells: a new front emerge in COVID19 treatment: mesenchymal stem cells therapy for SARS-CoV2 viral infection. Cytotherapy 2020 [Epub ahead of print]

12. Yin $\mathrm{K}$, Wang $\mathrm{S}$, Zhao RC. Exosomes from mesenchymal stem/stromal cells: a new therapeutic paradigm. Biomark Res 2019;7:8

13. Elahi FM, Farwell DG, Nolta JA, Anderson JD. Preclinical translation of exosomes derived from mesenchymal stem/ stromal cells. Stem Cells 2020;38:15-21

14. Taghavi-Farahabadi M, Mahmoudi M, Soudi S, Hashemi SM. Hypothesis for the management and treatment of the COVID-19-induced acute respiratory distress syndrome and lung injury using mesenchymal stem cell-derived exosomes. Med Hypotheses 2020;144:109865

15. Mahmoudi M, Taghavi Farahabadi M, Hashemi SM. Exosomes: mediators of immune regulation. Immunoregulation 2019;2:3-8

16. Shah TG, Predescu D, Predescu S. Mesenchymal stem cells-derived extracellular vesicles in acute respiratory distress syndrome: a review of current literature and potential future treatment options. Clin Transl Med 2019;8:25

17. Tisoncik JR, Korth MJ, Simmons CP, Farrar J, Martin TR, Katze MG. Into the eye of the cytokine storm. Microbiol Mol Biol Rev 2012;76:16-32

18. Sengupta V, Sengupta S, Lazo A, Woods P, Nolan A, Bremer N. Exosomes derived from bone marrow mesenchymal stem cells as treatment for severe COVID-19. Stem Cells Dev 2020;29:747-754

19. Tsuchiya A, Takeuchi S, Iwasawa T, Kumagai M, Sato T, Motegi S, Ishii Y, Koseki Y, Tomiyoshi K, Natsui K, Takeda N, Yoshida Y, Yamazaki F, Kojima Y, Watanabe Y, Kimura N, Tominaga K, Kamimura H, Takamura $M$, Terai S. Therapeutic potential of mesenchymal stem cells and their exosomes in severe novel coronavirus disease 2019 (COVID-19) cases. Inflamm Regen 2020;40:14 
20. Golchin A, Seyedjafari E, Ardeshirylajimi A. Mesenchymal stem cell therapy for COVID-19: present or future. Stem Cell Rev Rep 2020;16:427-433

21. Khakoo AY, Pati S, Anderson SA, Reid W, Elshal MF, Rovira II, Nguyen AT, Malide D, Combs CA, Hall G, Zhang J, Raffeld M, Rogers TB, Stetler-Stevenson W, Frank JA, Reitz M, Finkel T. Human mesenchymal stem cells exert potent antitumorigenic effects in a model of Kaposi's sarcoma. J Exp Med 2006;203:1235-1247

22. Li Y, Xu J, Shi W, Chen C, Shao Y, Zhu L, Lu W, Han $\mathrm{X}$. Mesenchymal stromal cell treatment prevents H9N2 avian influenza virus-induced acute lung injury in mice. Stem Cell Res Ther 2016;7:159

23. Curley GF, Jerkic M, Dixon S, Hogan G, Masterson C, O'Toole D, Devaney J, Laffey JG. Cryopreserved, xeno-free human umbilical cord mesenchymal stromal cells reduce lung injury severity and bacterial burden in rodent Escherichia coli-induced acute respiratory distress syndrome. Crit Care Med 2017;45:e202-e212

24. Nauta AJ, Fibbe WE. Immunomodulatory properties of mesenchymal stromal cells. Blood 2007;110:3499-3506

25. Choi H, Lee RH, Bazhanov N, Oh JY, Prockop DJ. Anti-inflammatory protein TSG-6 secreted by activated MSCs attenuates zymosan-induced mouse peritonitis by decreasing TLR2/NF- $\kappa \mathrm{B}$ signaling in resident macrophages. Blood 2011;118:330-338

26. Gorabi AM, Kiaie N, Barreto GE, Read MI, Tafti HA, Sahebkar A. The therapeutic potential of mesenchymal stem cell-derived exosomes in treatment of neurodegenerative diseases. Mol Neurobiol 2019;56:8157-8167

27. Davis ME. Exosomes: what do we love so much about them? Circ Res 2016;119:1280-1282

28. Kourembanas S. Exosomes: vehicles of intercellular signaling, biomarkers, and vectors of cell therapy. Annu Rev Physiol 2015;77:13-27

29. Blazquez R, Sanchez-Margallo FM, de la Rosa O, Dalemans W, Alvarez V, Tarazona R, Casado JG. Immunomodulatory potential of human adipose mesenchymal stem cells derived exosomes on in vitro stimulated $\mathrm{T}$ cells. Front Immunol 2014;5:556

30. Mokarizadeh A, Delirezh N, Morshedi A, Mosayebi G, Farshid AA, Dalir-Naghadeh B. Phenotypic modulation of auto-reactive cells by insertion of tolerogenic molecules via MSC-derived exosomes. Vet Res Forum 2012;3:257-261

31. Kadriyan H, Prasedya ES, Pieter NAL, Gaffar M, Punagi AQ, Bukhari A. The potential role of exosome on cytokine storm and treatment of severe COVID-19 infection. Bali Med J (Bali Med J) 2020;9:630-636

32. Zhu YG, Feng XM, Abbott J, Fang XH, Hao Q, Monsel A, Qu JM, Matthay MA, Lee JW. Human mesenchymal stem cell microvesicles for treatment of Escherichia coli endotoxin-induced acute lung injury in mice. Stem Cells 2014;32:116-125

33. Li JW, Wei L, Han Z, Chen Z. Mesenchymal stromal cells-derived exosomes alleviate ischemia/reperfusion injury in mouse lung by transporting anti-apoptotic miR- 21-5p. Eur J Pharmacol 2019;852:68-76

34. Monsel A, Zhu YG, Gennai S, Hao Q, Hu S, Rouby JJ, Rosenzwajg M, Matthay MA, Lee JW. Therapeutic effects of human mesenchymal stem cell-derived microvesicles in severe pneumonia in mice. Am J Respir Crit Care Med 2015;192:324-336

35. DeMarino C, Pleet ML, Cowen M, Barclay RA, Akpamagbo Y, Erickson J, Ndembi N, Charurat M, Jumare J, Bwala S, Alabi P, Hogan M, Gupta A, Noren Hooten N, Evans MK, Lepene B, Zhou W, Caputi M, Romerio F, Royal W 3rd, El-Hage N, Liotta LA, Kashanchi F. Antiretroviral drugs alter the content of extracellular vesicles from HIV-1-infected cells. Sci Rep 2018;8:7653

36. Gennai S, Monsel A, Hao Q, Park J, Matthay MA, Lee JW. Microvesicles derived from human mesenchymal stem cells restore alveolar fluid clearance in human lungs rejected for transplantation. Am J Transplant 2015;15:2404-2412

37. Khatri M, Richardson LA, Meulia T. Mesenchymal stem cell-derived extracellular vesicles attenuate influenza virus-induced acute lung injury in a pig model. Stem Cell Res Ther 2018;9:17

38. Tang XD, Shi L, Monsel A, Li XY, Zhu HL, Zhu YG, Qu JM. Mesenchymal stem cell microvesicles attenuate acute lung injury in mice partly mediated by Ang-1 mRNA. Stem Cells 2017;35:1849-1859

39. Hu S, Park J, Liu A, Lee J, Zhang X, Hao Q, Lee JW. Mesenchymal stem cell microvesicles restore protein permeability across primary cultures of injured human lung microvascular endothelial cells. Stem Cells Transl Med 2018;7:615-624

40. Varkouhi AK, Jerkic M, Ormesher L, Gagnon S, Goyal S, Rabani R, Masterson C, Spring C, Chen PZ, Gu FX, Dos Santos CC, Curley GF, Laffey JG. Extracellular vesicles from interferon- $\gamma$-primed human umbilical cord mesenchymal stromal cells reduce escherichia coli-induced acute lung injury in rats. Anesthesiology 2019;130:778-790

41. Park J, Kim S, Lim H, Liu A, Hu S, Lee J, Zhuo H, Hao Q, Matthay MA, Lee JW. Therapeutic effects of human mesenchymal stem cell microvesicles in an ex vivo perfused human lung injured with severe $E$. coli pneumonia. Thorax 2019;74:43-50

42. Li X, Corbett AL, Taatizadeh E, Tasnim N, Little JP, Garnis C, Daugaard M, Guns E, Hoorfar M, Li ITS. Challenges and opportunities in exosome research-Perspectives from biology, engineering, and cancer therapy. APL Bioeng 2019;3:011503

43. Witwer KW, Van Balkom BWM, Bruno S, Choo A, Dominici $M$, Gimona $M$, Hill AF, De Kleijn D, Koh M, Lai RC, Mitsialis SA, Ortiz LA, Rohde E, Asada T, Toh WS, Weiss DJ, Zheng L, Giebel B, Lim SK. Defining mesenchymal stromal cell (MSC)-derived small extracellular vesicles for therapeutic applications. J Extracell Vesicles 2019;8:1609206

44. Greening DW, Xu R, Ji H, Tauro BJ, Simpson RJ. A protocol for exosome isolation and characterization: evaluation of ultracentrifugation, density-gradient separation, and im- 
munoaffinity capture methods. Methods Mol Biol 2015; 1295:179-209

45. Ludwig N, Whiteside TL, Reichert TE. Challenges in exosome isolation and analysis in health and disease. Int $\mathrm{J} \mathrm{Mol}$ Sci 2019;20:4684

46. Ludwig N, Yerneni SS, Razzo BM, Whiteside TL. Exosomes from HNSCC promote angiogenesis through reprogram- ming of endothelial cells. Mol Cancer Res 2018;16:17981808

47. Chettimada S, Lorenz DR, Misra V, Dillon ST, Reeves RK, Manickam C, Morgello S, Kirk GD, Mehta SH, Gabuzda D. Exosome markers associated with immune activation and oxidative stress in HIV patients on antiretroviral therapy. Sci Rep 2018;8:7227 